\title{
3
}

\section{IMMERSION IN RURAL AMERICA}

\section{The case of Bushler Bay ${ }^{1}$}

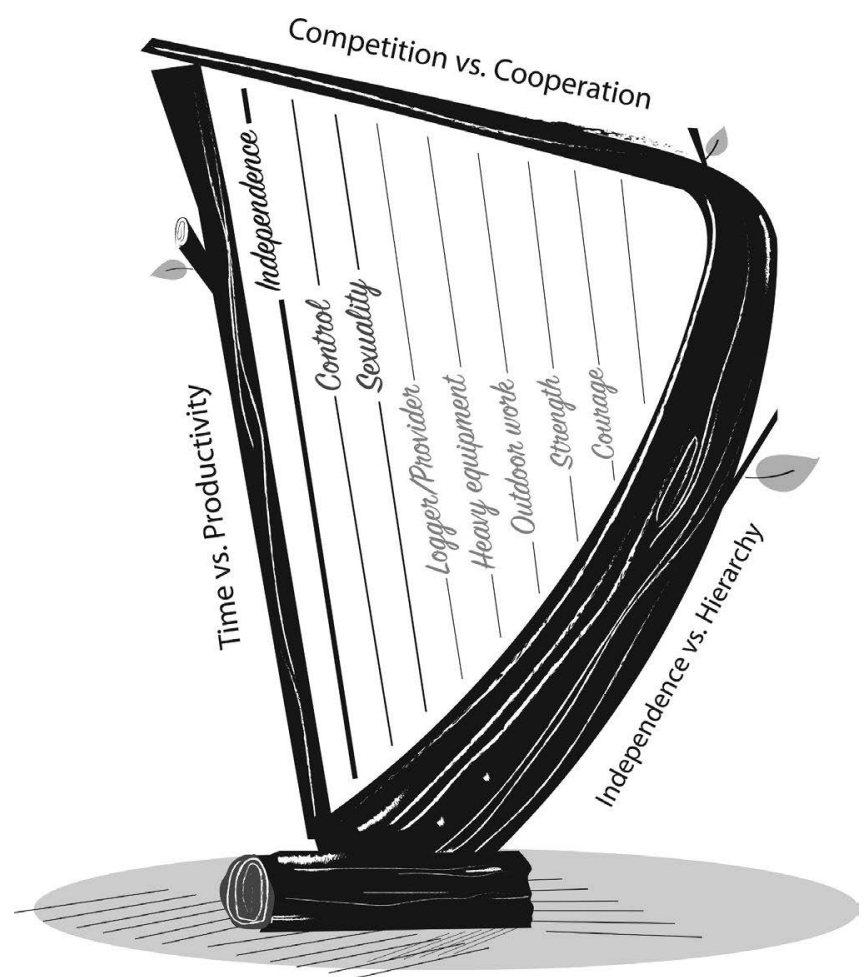

A Bushler Bay Logger

Harp Example 


\section{Introduction and reflection}

In late 1972, my then-husband, Michael, and I moved to Bushler Bay, Washington, where we were hired as 'on-site researchers' by Abt Associates. ${ }^{2}$ The need to care for our young daughter (then three), our near-final stage in obtaining our doctorates and our interest in coming up with more equitable gender roles led us to suggest job-sharing to our future employers. We argued that this would grant them the expertise of two people and the likelihood of $>50 \%$ time investment from each of us for the same salary and benefits. We convinced them that this was a sufficiently 'cutting-edge' idea for them to try it out.

Our doctoral programmes at the University of Washington had not prepared us for research in rural America-we'd expected to work in the Middle East-so we weren't at all sure what we would find in the two research communities. We arrived in the smaller community mid-winter, having just bought a Dodge pickup truck, partly as a potential rapport builder with the loggers we imagined we would (and did) find and partly because of Michael's rural American, masculine fascination with trucks. ${ }^{3}$

At the time, I was newly aware of the degree to which women were disadvantaged professionally. I'd begun going to 'consciousness raising groups' and 'assertiveness training' to address gender inequities personally; Michael supported me in these efforts.

In those days, anthropologists were expected to avoid influencing local cultures, and we struggled with this dictate, given our concerns about gender roles and sexual politics in general. Our decision: To avoid any 'proselytizing' but to be honest about our own preferences and practices, which were quite strange to our neighbours. We recognized that our knowledge of English, shared ethnicity ${ }^{4}$ and familiarity with American culture generally were advantages, but that we would also have to struggle to minimize our own cultural assumptions and biases as we viewed local realities.

Anthropologists tend to be drawn to cultures that differ from their own; it's a central reason many study anthropology. We are intrigued by 'the other'. In this rural American context, there were two groups, described later, one of which (the 'Locals'), ${ }^{5}$ more different from my own background, aroused my curiosity. Although I recognized that Local views were more antithetical to feminism, which I embraced enthusiastically, I still found their independence and disdain for middle-class conformity appealing. Recognizing this conflict, I also found Local men's more overt sexuality attractive.

One version - of many possibilities - of a logger's common harp is reflected in the image under this chapter's heading. The differing shadings of the strings reflect clustering and importance, with the thicker strings more commonly admired within the value system represented. To put our findings in context, we need to reflect a bit on the environmental setting in which these tones and clusters are selected and 'songs' created. 


\section{Forests and the environment}

Bushler Bay, comprising two unincorporated communities (one of 550 people, the other 250 (Colfer, Cerveny, and Hummel 2019), sits on the Eastern shore of the Olympic Peninsula, bordering Hood Canal (in Puget Sound; Figure 3.1). The area was (and remains) sparsely populated, with dense rainforests to the west and south. To the flatter north, though still forested, there were more agricultural fields interspersed with forested area. Bushler Bay's economy was largely dependent on logging throughout the 20th century until national concerns about the spotted owl (Strix occidentalis) and the marbled murrelet (Brachyramphus marmoratus) spawned the 'Timber Wars' (Colfer 2018), eventually closing down much of the timber production ${ }^{6}$ on the east side of the Peninsula. Families routinely engaged in hunting, fishing and collection of non-timber forest products, like mushrooms, a wide variety of berries and firewood, with several small industries collecting brush, particularly salal (Gaultheria shallon). ${ }^{7}$

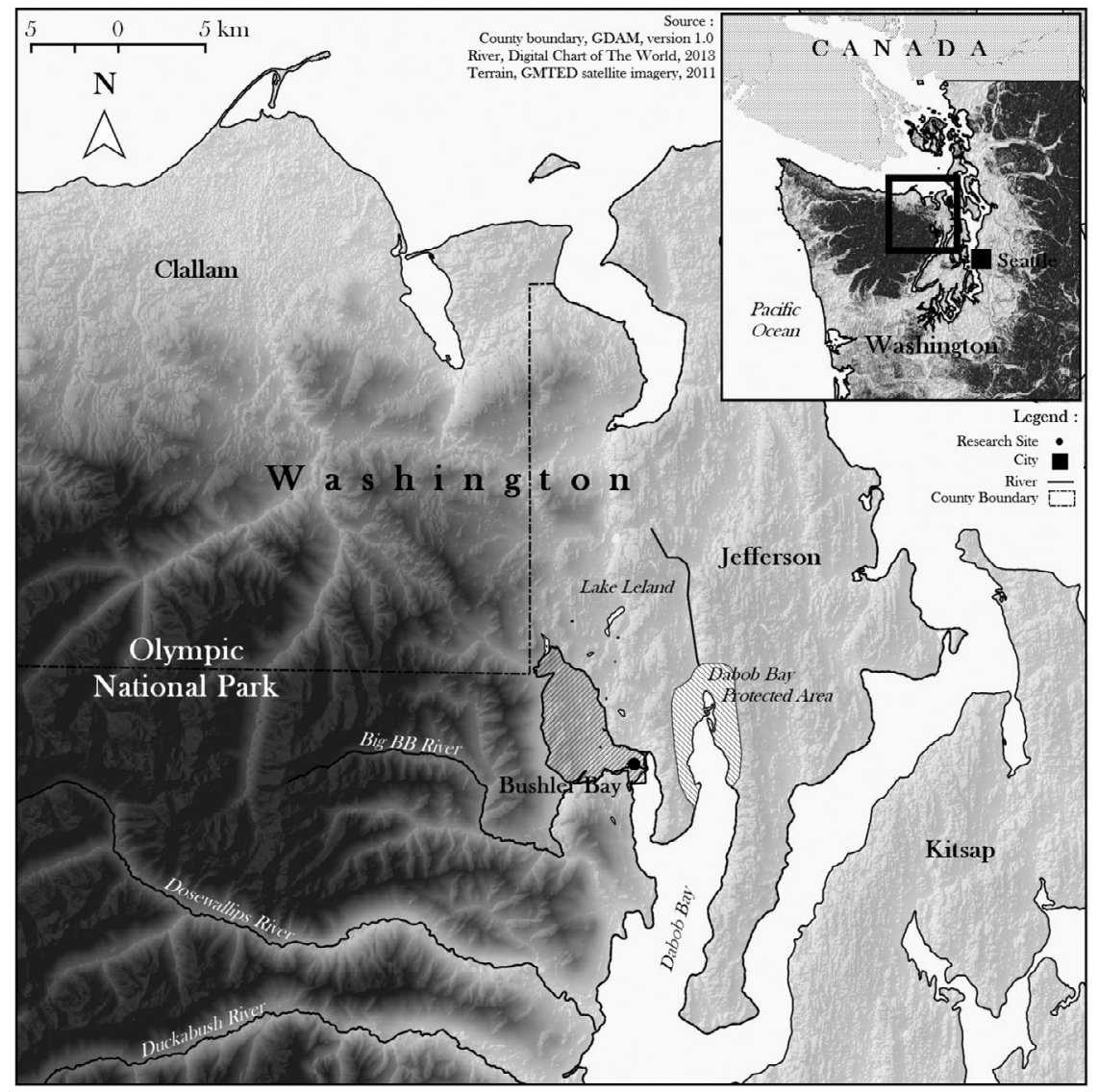

FIGURE 3.1 Map of Bushler Bay and surroundings. 
Topography is steep and covered with dense stands of Douglas fir (Pseudotsuga menziesii), cedar (Callitropsis nootkatensis) and hemlock (Tsuga heterophylla), Washington's state tree. Land ownership and management represented a mosaic, including large- and small-scale private ownership, but most lands on the Olympic Peninsula were (and remain) managed as part of the Olympic National Forest and National Park.

Formal forest managers from the US Forest Service were very evident in day-to-day life, intimately involved in managing this valuable forest for sustainable timber production, most obviously in taking bids and letting contracts for timber sales to loggers. Most policies were crafted in an explicitly top-down manner in distant Washington, DC. I remember one community meeting called to record the views of locals on several management options (including the creation of an inaccessible wilderness area), without apparent influence on ultimate decisions taken. Otherwise, government regulations were followed and enforced by USFS personnel. Large-scale private management was fairly similar at that time, with managers also obtaining bids and letting contracts to local loggers. Smaller-scale owners had comparative freedom to manage as they chose.

Pingree and DeLuca's (2018) study just south of Bushler Bay provides a nice introduction to the area, which falls:

within the North Pacific maritime dry mesic T. heterophylla/P. menziesii potential vegetation zone, between 400 and $600 \mathrm{~m}$ in elevation . . . Soils of the northern and eastern Olympic Peninsula are formed on marine deposits of basalt, colluvium, volcanic ash, and glacial till.

Soils were classified within the US Soil Taxonomy classification as Haploxerepts (NRCS, 2014):

A volcanic ash layer was present at [two] sites . . Mean annual temperature from 1980 to 2010 averaged $8.1 \pm 0.5^{\circ} \mathrm{C}$ and mean annual precipitation was $2181 \pm 592 \mathrm{~mm}$ across all sites . . . The Hargreaves climate moisture deficit ranged from 145-291 across all sites and is reported as the sum of the monthly difference between the potential and actual moisture deficit

Burwell (n.d.) describes the history of fire danger, which was minimal until this century, when fires have increased, partially because of changed management practices and drier conditions.

In the following discussion, I return to the 'cultural harp' analogy raised in Chapter 1. As noted earlier, the harp itself represents the comparative stability of cultures. In these two communities, we might consider the harp ${ }^{8}$ to have its usual three sides: in this context, one relates to people's perceptions of time, the second to a balance between competition and cooperation and the third deals with the balance 
between independence and hierarchy. These are alluded to in the following sections, which place the strings on this harp in cultural perspective. Men from these communities (and to some extent, women as well) have the option of 'plucking' one or another of these strings at any given moment. Each man can create his own 'chords' and 'song' based on the strings he opts to pluck. Recognizing this freedom allows us to capture the variety and dynamism of gendered ideas and behaviour.

\section{Masculinities and the provider harp string}

On arrival, A.M. Colfer and I quickly became immersed in the planning process for what was called locally 'the federal project'. The project was led by one of the school teachers, with help from several others; an important component of the project was to mould the curriculum in such a way as to make it more welcoming for local youth, particularly boys, among whom the motivation to succeed in school was minimal; the boys' dropout rate was high (as in Kalimantan, Chapter 4). There were several older community members who participated actively, helping to craft the proposal and begin implementation. Almost all the planners were men, most middle aged or older; the key decision-makers were all men.

Very quickly we learned one of the central features (or notes on the harp) of masculinity throughout the community: men were seen as the breadwinners. ${ }^{9}$ Indeed, this was one of the few elements of masculinity shared between community groups - though the manifestation of breadwinning differed. Coming into the community, Michael and I presented ourselves as equally involved in the research project, equally employed. Yet whenever I was introduced to someone new, this got transmuted into my being "married to Michael, who works for the federal project". This perception continued throughout the three years we lived there, despite our frequent corrections.

It wasn't as though no women worked. Bushler Bay School represented the only real cluster of employed women in 1971-1972, including 15 women and 16 men. ${ }^{10}$ But careful analysis of these figures revealed several patterns that reinforced and reflected both men's expected roles as breadwinners and their greater importance in work settings: First, men dominated the higher status, certified (teaching) staff: 13 men, 4 women; and women dominated the non-certified (kitchen, maintenance) staff: 3 men, 11 women. Second, men's jobs were treated as important, women's not so much.

- Men held all administrative positions (superintendent, principals, head of the federal project) and taught the higher status 'men's subjects' (math, science, social studies) as well as woodshop and coaching; women taught little children or 'women's subjects' (English, writing, reading).

- Men predominated in high school, considered to require greater expertise, while women taught the lower grades.

- Men tended to have clearly defined contracts with reasonable job security, whereas women were often hired from year to year (not knowing, for instance, during the summer if they'd be employed in the fall). 
- Negotiations over wages or promotion were private for men; public (conducted during school board meetings), embarrassing and demonstrably less successful for women.

Age, another social structural principle in the community, intersected with gender. Almost all men who taught or administered in school were in their 30s and 40s, their 'prime of life', enmeshed in their masculine role as breadwinner; women were mostly represented at the extremes: single and in their 20 s or in their 50s. This school context, in which boys (and girls) were locked for six hours a day, 280 days a year, for 12 years, provided a powerful statement about what the broader society expected of men (and women) with different qualifications and at different ages, and what the associated benefits were.

Overall, the community sentiment was that men needed their jobs and that women worked for 'extras', even when the evidence suggested otherwise. ${ }^{11}$ Many men, particularly those long-resident in the community (Locals, discussed below), tended to object to their wives working, considering it an affront to their ability to support the family. This was a somewhat moot point, with so few employment opportunities for women. Women also expressed their reluctance to have a job that paid more than their husband earned. ${ }^{12}$ There was some evidence that periods of men's unemployment (common among Locals) resulted in more marital discord. Certainly, that was women's perception.

\section{Masculinities and the sports harp string}

Besides the school as a work setting providing a daily reminder of culturally appropriate roles for men and women, ${ }^{13}$ one of its key functions was to organize sports events. Such events were the most visible form of entertainment for the community, especially during the bleak winter months. ${ }^{14}$ A high school basketball game was colourful, active, entertaining and watched and appreciated by all sectors of the community. It was also a vivid portrayal of gender roles. ${ }^{15}$ The team members, boys, were chosen for their strength and athletic prowess. Cheerleaders were selected based on beauty and popularity. ${ }^{16}$ Little boys idolized the players and little girls longed to become cheerleaders.

A basketball game was rife with symbolism. The team members shared one uniform, cheerleaders another. As the national anthem played to signal that the game was about to begin, the two opposing teams were arranged diagonally across the court, players in the centre, with their respective cheerleaders on the ends of the diagonal. Players - the central stars of this event-were segregated from the audience by their seating, their access to the courts and their sole access to the locker room. Cheerleaders also had their own space, standing together near one basket. They took over the court whenever the boys vacated. They provided snacks for the team and for audiences at home games. Their primary role was to instill 'school spirit' and stimulate audience support for the team, which was expressed by loud cheering. ${ }^{17}$ Their cheers both urged the team on and reassured them when they failed. 
The team's role was to win games. They did this by striving for cooperation, organization and teamwork in their play, within a context of hierarchy where

'men control other men' ... [T] he referees decide when a foul or transgression has occurred, and players comply; the principal reminds people not to walk on the floor, and by and large they do not; the coach directs the team's play; and the captain of the team makes decisions about the team's strategy and time-outs.

(Colfer and Colfer 1979, p. 191)

The 'hidden curriculum' of a game demonstrated expected livelihood roles for men-to work with other men within hierarchical contexts, where groups competed against each other. ${ }^{18}$ But it also portrayed the marital roles for men and women. ${ }^{19}$ What mattered in a game was who won. The girls could provide emotional support, but they could never score a point, just as most Bushler Bay wives could not contribute to household income. ${ }^{20}$ The importance of this curriculum was manifest in wide attendance at games, periodic community controversies about coaches, a preoccupation with the behaviour of players (and cheerleaders), community interest in the events and a general concern about the win-loss records of the team.

In addition to these recurrent representations of gender roles at games, the importance of school sports was solidified every spring when an election to pass the 'school levy' was held. The levy was needed to supplement the funds available to run the school, and every year, cutting the sports programme was floated as a possible outcome should the levy fail. This issue was passionately debated in the community, with some men particularly adamant about the importance of sports for boys. All recognized and valued its role as community entertainment. But there was a more visceral attachment to it among one community group, Local men. They argued that sports taught boys to be men, to compete (as they would have to do in the world of work), ${ }^{21}$ to cooperate as a team, to learn leadership and to strengthen their bodies physically.

Cooperation and competition were concepts that came up routinely. When Locals talked about young boys learning to be men, they stressed the significance of competition. They saw a competitive world 'out there' in which boys would need to strive to excel. Yet interestingly, local work patterns were remarkably cooperative. The danger of their work meant they relied on each other for their very lives. They were not in fact competing on a particular job; each had a specific role at a given time, and they were complementing each other's actions.

Among Public Employees, the emphasis at work was explicitly on cooperation within a given unit, competition reserved for other units (for funding, for personnel, for equipment, in segmentary opposition; Colfer 1975). This was clearly taught in the school, where one grade would cooperate internally to compete against another, girls would work together to win out over boys, who were likewise cooperating among themselves. 
Competition, so closely tied to masculinity for Locals, was conceived as cooperation's opposite. Men were seen to be competitive and women cooperative; yet clearly in real life, whether Local or Public Employee, man or woman, both competed and cooperated. We came to see it as a cultural balancing act.

\section{Two ideals of masculinity}

The divide between Locals and Public Employees only gradually dawned on us (Colfer and Colfer 1978), although differences in dress should have tipped us off. ${ }^{22}$ Logging was the preeminent exemplar of the Local way of life, and loggers had a distinctive dress: [often dirty] baggy jeans, red Logger's World suspenders and caulk boots. Different public institutions required different dress, with US Forest Service personnel, the stereotypical exemplar of the Public Employee lifestyle, wearing green uniforms. In institutions without uniforms, Public Employees tended to wear neat slacks with collared shirts and sometimes ties. In general, Locals dressed less formally than Public Employees. ${ }^{23}$

School personnel and other Public Employees spoke of this Local-Public Employee differentiation as one of social class. ${ }^{24}$ But we found viewing it as cultural difference made more sense. Those Public Employees labelled 'lower class' ('Locals') included a great variety of qualities incompatible with that classification. ${ }^{25}$ There were wealthy people, educated people, people of longstanding residence, mixed in with others who might be widely termed 'lower class', all sharing identifiable and shared predilections.

The more I have thought about 'class' in the US, the more convinced I have become that such an appellation effectively reinforces and replicates the existing power structure, rather than clarifying differences among groups. Those with 'middle-class' values define what constitutes prestige and value. And they have a full arsenal of weapons, not least of which is control of the school systems - to which all American children go every day. Here, I use a variety of kinds of encounters to present the evidence of different masculinities-different selections of 'notes' on the harp-among these two groups. ${ }^{26}$

The variation in the use and perceptions of time between the two groups makes a nice segue from the presentation of masculinity in the Public-Employeedominated school context. In school, as in the bureaucracies where Public Employee men worked, ${ }^{27}$ time structured life. Students and employees had to be at work on time, events and meetings were set for specific times, deadlines were set and punctuality was both expected and rewarded. Being on time and meeting deadlines (among other things) were evidence of good job performance. Success within bureaucracies was also not unrelated to length of time on the job. My roughly 24 years in the American educational systems by then prepared me well for this orientation to time.

Local men, however, enmeshed as they were in non-bureaucratic settingslogging crews, oyster culture, family businesses - tended to see following timetables as irrelevant. They evaluated their own work based on production (number 
of logs to the landing) and income earned. Time was mainly relevant insofar as it could indicate efficiency.

The link with masculinities, typically contrasted in this setting with femininity, was strengthened by the fact that both Local and Public Employee women-as primary caretakers of their children-remained enmeshed in the school's somewhat arbitrary timetables. Additionally, the efficient accomplishment of women's usual tasks was difficult given the necessarily responsive nature of caretaking. Cooking dinner or doing the laundry could not always be done efficiently: a child might need his diaper changed or an elder have a medical emergency. Nor did it behoove women to assess the value of their efforts by income earned. Gathering, gardening, canning, handicrafts - the ways women without formal jobs typically spent their time-were notoriously unprofitable in terms of income. Women more often assessed their work in terms of time spent rather than either amount produced or money made.

Local men's approach to time became a feature of their masculinity, strengthening their cultural conflict with Public Employees and with women-multivalent conflicts, as shown next.

\section{Masculinities and the control harp string}

The control harp string begins with men's control of their own emotions. As with the men in my own families (Chapter 2), Bushler Bay's men, neither Locals nor Public Employees, cried in public or to my knowledge, in private. ${ }^{28}$ They were unlikely to discuss their emotions, except in the most intimate of circumstances and many avoided the topic even then.

Local men were more overt about demonstrating control over women than Public Employee men (though the school's 'hidden curriculum', described earlier, shows Public Employee men's dominance as well-just more subtly). Some Local men believed they had the right as men to 'rule the roost' at home. That might mean ordering a wife to 'get me a beer', 'go buy cigarettes', 'shut those kids up', etc. My own suspicion is that when the 'breadwinner string' on the cultural harp was out of kilter, the 'ruling the roost' string was more likely to be twanged. ${ }^{29}$ Jokes about a man as 'pussy whupped' (ruled by his wife, unable to resist her sexuality and exert manly control), for instance, were a common and humorous way men could differentiate themselves from a man so marginalized and from women in general. Accusing someone else of this 'failing' also reinforced one's own position as in control at home.

In both Local and Public Employee households there tended to be a simple expectation that of course a man's wife would cook dinner, maintain a clean house, do the laundry and take care of the children. The commitment of Public Employee couples to replicating an idealized form of middle-class life-nice house and car, mowed lawn, more formal and stylish clothing-meant a greater interest in having these tasks performed well than was found among Locals. This may have resulted in stronger if more subtle pressure on the Public Employee 
wife to keep a cleaner house, prepare more complex meals, etc. The greater commitment to 'togetherness' for Public Employee married couples also meant such wives were subject to more husbandly monitoring of their behaviour than were Local wives.

The response to Michael's and my [locally perceived] peculiar division of labour-alternating childcare daily, sharing domestic tasks evenly-differed between groups. Public Employees clearly found it odd but did not, to my knowledge, criticize. Some men would admit to sharing some of the childcare but drew the line at changing a diaper or doing the dishes, tasks that carried extra symbolic weight as unmanly.

Among some Locals, however, our division of labour was cause for utter disdain. I remember sitting with an older Local couple at a party. Michael said something in passing about what he'd cooked for dinner. The wife gave him a withering look and asked sarcastically if he wore a frilly apron when he cooked. ${ }^{30}$ She was clearly challenging his masculinity and expressing her disapproval. I was told that some Locals considered me a 'ball buster' (a dominating woman who destroys a man's masculinity), partly because of my feminist leanings but also probably because of Michael's willingness to share domestic tasks.

Another occasion in which my purported 'ball busting' came to the fore was at the Whistling Oyster Tavern, the only night-time recreational setting in town and one where Locals (unlike Public Employees) tended to gather. The tavern provided alcohol, music and several games like foosball and billiards. This particular winter evening, I was on a roll and, unusually, doing very well at the various games. Indeed, I kept on winning. Eventually, two women, separately, came to me with friendly warnings: "Quit winning", "Let the men win". They worried that the men would be upset. I sensed a worry about violence somehow-though I was never entirely clear what they thought the men might do. Or perhaps they feared that continued winning could worsen my reputation as a 'ball buster'. I never felt in danger nor did I see or hear of evidence of physical abuse (though it probably sometimes happened). I suspect these warnings were prompted by the women's sense of responsibility for men's emotional health, which included the men's security in their own masculinity (doubly endangered when unemployed, so common in winter). Robinson and Hockey (2011) found a similar idea in northern England:

Women's interviews showed that a capacity for empathic warmth, a commitment to emotional expressivity, and a felt concern at the prospect of any threat to a man's emotional well-being were seen, by women, and men, as desirable and indeed necessary qualities that were intrinsic to femininity.

(p. 170)

Women reinforce these cultural notions of masculinity and femininity as well as men. 


\section{Masculinities and the strength and courage harp strings}

Local men, in reference to their own masculinity, first stressed physical strength and dangerous, outdoor work. The simple fact of working outdoors implied an ability to withstand difficult weather (rain, snow, heat), and it typically included an appreciation for the beauty of the woods. Many loggers found painful the environmentalists' common accusation that loggers were destroyers; most saw themselves as providing a valuable product for society in an [under-appreciated] efficient and sustainable manner.

Considerable physical strength and skill are necessary to handle a commercial chainsaw $^{31}$ and the other heavy equipment used in logging. Metropolitan Life Insurance Company rated Pacific Coast lumbermen as the worst risk for 'death by violent accident' (Newsweek 1974), ${ }^{32}$ and everyone in town knew people who'd been killed or maimed by a falling tree or upturned log truck. Climbing up a tree to cut off the top was among the most dangerous. Reed (2003) documents similar, more recent dangers in logging on nearby Vancouver Island; Carroll (1985) describes Oregon loggers' pride in both their levels of skill and their courage $^{33}$ in confronting danger. The manly occupation of logging is routinely contrasted with bureaucrats' 'paper-shuffling' and with women's work.

The words on a log truck driver's T-shirt in Oregon sum up a common Local view: "If you ain't a logger, you ain't shit", a sentiment expressed more genteelly in Carroll (1985). This combined the idealization of logging with some important interactional qualities (lack of regard for 'proper' grammar, straight speaking and easy use of profanity), which served also to differentiate Locals from Public Employees and women.

Local men eschew words like 'please', 'thank you', 'do you mind?'. A. Michael Colfer's 1974 fieldnotes capture this attitude:

We three stood at the end of the bar picking up beer for a party. The young logger was hosting at his home, and we were getting supplies at the tavern and the store. The three of us were laughing and enjoying ourselves. The Public Employee (not, incidentally, a Forest Service employee) tried for the third time to pay for part of the beer. Again, the logger refused.

"Shit, man, I'll pay for my part".

"Nah, I don't want your dirty ol' money".

"Take it. Please".

The word was like a red flag.

"Don't give me that Forest Service shit!"

(Colfer and Colfer 1979, p. 45)

Carroll (1985) emphasized Oregon loggers' commitment to their own independence. As men, they wanted to be able to determine their own lives, not to be subject to a boss's dictates, and have the freedom to quit any job they did not like. ${ }^{34}$ 
These were sentiments reiterated often in Bushler Bay, where at that time loggingrequiring both strength and courage-was still a successful livelihood strategy. Independence, manhood and logging were intimately connected for Locals. ${ }^{35}$

\section{BOX 3.1 A LOGGER'S CHORD-BREADWINNING, INDEPENDENCE AND DIFFERENTIATION FROM WOMEN}

The breadwinner harp string sometimes conflicted with the Local independence string, when for instance a logging boss exerted his supposed authority, or a co-worker questioned a man's competence. The manly thing to do in such circumstances was to quit that job and seek another in the woods. The sexuality harp string had an impact as well: Other loggers admired a man's independence, whereas his wife might value his breadwinning more. In the US at that time many saw gender relations as a 'battle of the sexes', in which all men were pitted against all women. A man who paid attention to his wife's concerns about his breadwinning was in danger of being considered 'pussy whupped'. The greater adherence among Public Employees to the breadwinner role and to related security put these officials closer to the category of women and earned them a reputation as 'paper pushing lackeys of the bureaucracy'. ${ }^{36}$

This enthusiasm for independence was rarely expressed by Public Employees, who recognized and tended to accept their dependence on their bureaucratic hierarchy. They traded independence on the job-a Local choice of tone on the harp-for security and reliable benefits, which they linked to the reliable breadwinner string. Although Public Employees also complained about their bureaucracies, many saw value in working within one. They were part of a cadre of people with common goals, they were (distantly) linked to the nation's political and decision-making centre, and some appreciated the simplicity of having someone else making day-to-day decisions about the work to be done. Their jobs in a bureaucracy allowed them to pursue the 'middle-class' lifestyle they sought. Bureaucracy and hierarchy did not appear to link directly or negatively with masculinity (also seen in Sitiung, Chapter 5).

As noted earlier, having an occupation was a crucial element of men's identity, a particularly important tone on their harp, for both Locals and Public Employees. But among Public Employees their profession was more closely linked to the breadwinner tone than for loggers (who typically had periods of unemployment every year). The latter saw their profession as intrinsically valuable and good, a source of pride closely linked, via strength and courage, to manhood.

\section{Masculinities and sexuality}

Altork (1995), an anthropologist, in examining her own behaviour and attitudes toward sexuality in the field (in neighbouring rural Idaho), recounts her attraction 
to the firefighters she studied. This quotation from her writing captures both the inherent sexuality of this dangerous outdoor work (within the rural northwestern American context) and the ambivalent attractiveness of it to (American) womena response I also experienced. Altork had asked to photograph two men friends out on firefighting duty; one had suggested they clean up first. The other responded:

'What do you mean? This is how we look out there, man! This is what it's all about - men and machines, sweat and grit. Why wash it off?' Turning to me, his face opening into the grin of the heartbreaker, he adds, 'Hey, Katie, this is the way it really is, right? It's hot and heavy work. But, what the heck, it's kind of sexy, don't you think?' And then, looking me full in the face, he winked. And I winked back.

In Bushler Bay, Local and Public Employee attitudes about sexuality varied, particularly in how public it was-and thus how much access I had to people's views about it. Public Employees were unlikely to talk about sex in public, discuss marital infidelity openly or act in sexually demonstrative ways. Their dancing was usually restrained; any marital infidelity was carried out with utmost discretion. Public Employees tended to disapprove publicly of non-marital sexuality at any age.

Locals were much more open about the topic. Local men might brag about their 'conquests', and some women readily admitted to such adventures as well. Among both genders, many considered infidelity more of a peccadillo than a serious offense. Sexually active Local girls and women, unlike boys or men, endured some disapproval, but Local attitudes were much more forgiving of female sexuality than were Public Employees'. Sexuality among Locals was ultimately considered a personal decision for both sexes. Public Employees expressed disapproval of this attitude, and stronger disapproval of overt female sexuality. Pascoe (2007) describes the subtler but pervasive reinforcement by school personnel of heteronormativity in the California school she studied, which of course implicitly requires female sexuality.

Sexuality is related to gender everywhere, but its relevance was very overt among Local men. In day to day discourse, sexual innuendo was common: A $\log$ truck driver would refer to his logging rig as 'my Peter' ${ }^{37}$ A bumper sticker advertised "Old loggers never die; they just get a new Peterbilt." 38 The symbolic relationship in Local men's minds between large logs, powerful machines, strong men and sexuality was clear. ${ }^{39}$

Women appreciated and reinforced this link. Young girls were drawn to those boys who excelled in sports or other physically demanding tasks. ${ }^{40}$ This excerpt from A.M. Colfer's 1973 field notes captures a common feeling:

We sat in her living room talking about the school, local life, and logging. At one point she got up and went into the other room, bringing back with her a blown-up photograph of her husband in hard hat and overalls standing beside the log that he had just cut down-it filled the log truck. 
"You can talk about the romance of various occupations all you want," she said, "but it's going to be pretty hard to beat that". She looked up, smiled proudly, and added, "Now there's a man!"

(Colfer and Colfer 1979, p. 39)

Research by Reed (2003) in nearby Canada showed that

women who identified themselves within 'traditional' feminine relationships such as helpmates and wives as well as women who self-identified as participants and partners in forestry occupations suggested that feminine identity in forestry communities were [sic] locally and mutually constituted with those of men's masculine identities.

Adultery was common in the community, as was marital instability. Relations between many Local husbands and wives were full of suspicion. The atmosphere at Local parties, which typically involved considerable alcohol consumption, was one of sexual electricity. Men and women interacted with people other than their spouses, danced with each other (often with explicit sexual moves), argued with each other and some might disappear into the nearby forest for an illicit rendezvous. Many Locals had known each other since childhood, with their romantic histories and associated potential jealousies known and remembered. Unlike my father's attitude (that he should violently protect my mother from unwanted attentions), I never witnessed a fight between men over women. Men tended to withdraw in the face of wifely flirtations with others. And unwanted attentions were gently and effectively discouraged more subtly, by laughter, words and/or meaningful looks from friends, both men and women.

Public Employees tended to gather in smaller groups, segregated from Locals, with the emphasis on couple to couple interaction, rather than people operating socially as individuals. Any sexual attraction was kept strictly under control in public.

Although Local women complained about their husbands' infidelity, one concluded "but, you know, even though I have to put up with a lot of shit, I know he's a real man. I wouldn't want to trade that" (Colfer and Colfer 1979, p. 39).

In mid-1977, after I'd left the community, I conducted an anonymous survey. Among other things, I asked a series of questions about the various birth control options available. To my great surprise, $23 \%$ of the 26 respondents' husbands had had a vasectomy (Colfer 1977, p. 51). In the three years of my fieldwork, only one Public Employee wife, my closest friend there, had told me about her husband's vasectomy. I'd heard several men say that they'd never have one and that birth control was the woman's responsibility. ${ }^{41}$ Vasectomies were explicitly seen as attacks on their manhood (as expressed by my maternal grandfather), at least publicly. I have no way of knowing what the proportion of Local visà-vis Public Employee respondents was. But if there was a significant number of Locals in the group, the fact that the women kept their husbands' secret was 
interesting in itself - a strong statement on the depth of feeling among men (and perhaps related fears among women, who may not have wanted their husband's masculinity questioned).

\section{Dominant masculinities summarized}

Ideology, men's characteristics and interests and gender roles are some of the ways masculinities are framed and practised. Below I highlight those most consistently and publicly visible in Bushler Bay. As noted in Chapter 1, men in all cultures have some choice about the harp strings they pluck, constrained by the harp(s) of their contexts.

\section{Ideology}

The Bushler Bay community manifested a clear ideology of difference between men and women, with an expectation of men's dominance as something 'natural', related to men's and women's inherent natures.

\section{Characteristics}

Men were expected, particularly among Locals, to be strong, courageous, competitive, independent and dominant within the home. Among Public Employees, strength and courage were admired. Cooperation within one's bureaucratic work unit was emphasized, with competition reserved for other units, other sectors. Dominance within the home was more implicit, assumed, than among Locals.

\section{Interests}

Heavy equipment, sports, sexuality and being outdoors were key interests for many men of both groups, though more intense for Locals. Public Employee men tended also to be concerned with fulfilling middle-class expectations (nice home and car, secure employment, 'proper' clothing). Men in both groups showed an interest in differentiating themselves from the other group.

\section{Gender roles}

Being a breadwinner was an expectation for both Local and Public Employee men, though it was more central for Public Employees generally than for Locals. Although most men were fathers, this role was not stressed publicly (parenting often left largely to wives).

\section{Bushler Bay men in forests: conclusions}

There was a 'division of labour' in Bushler Bay, with many Locals directly dependent on the forest and its harvest for their livelihoods. Public Employee 
men, unlike the loggers, were intimately involved in national and state natural resource management hierarchies, particularly related to forests, via their roles as breadwinners. Politics at the local level were far more the domain of women (Colfer 1977) — so different from the Indonesian contexts to follow. Clubs provided most local services (streetlights, fire protection, entertainment, adult education) performed elsewhere by formal governance structures. Women were seen to have more time for such activities. Volunteer firemen were at that time all men, which fit both with the availability of men trained in fire suppression from the US Forest Service - though the environment was so wet that forest fires were rare and small — and with experience and appreciation of heavy equipment.

The level of conflict increased steadily during this period, as the federal government expanded its involvement in forest management, from timber harvest and replanting to attention to biodiversity losses. Pressures from environmental groups, trying to save the spotted owl and marbled murrelet, were another key factor, with the beginnings of adverse effects on Local livelihoods, and ultimately, on US Forest Service personnel with an interest in remaining in Bushler Bay.

Much forest-related masculine humor in the 1970s was dark and revolved around the spotted owl. It reflected the real dangers to people's livelihoods and specifically to men's employment in the woods, so central to loggers' selfimage: Printed on a T-shirt, 'Save a logger, kill a spotted owl', or the offering of 'spotted owl soup' on the menu at the local cafe. Laughter spurred by these jokes identified an individual as opposed to environmentalists, while simultaneously serving to identify him as on the side of loggers in local resource conflicts (see Meyer's (2000) discussion of the unifying and divisive functions of humor).

The identities and livelihoods of Local men (and their families), so bound up in the 'song' of physical, outdoor activity focused on producing timber, were in serious danger (see Chapter 7 for a 2017 update). There were few obvious alternatives that required those skills and interests. Public Employee men employed in natural resource management were also endangered as budgets were cut and national attitudes toward foresters deteriorated. Both loggers and foresters came to be seen by many as 'forest destroyers', with the latter seen as responsible for unsustainable management. The definition of sustainability changed from simply sustaining timber harvests to sustaining the far more complex forest and its non-human inhabitants.

The people of Bushler Bay, like the Kenyah of Long Segar (Chapter 4), were suffering from policies crafted in distant urban centres over which the local community had no significant influence.

In 1975, we left our home in Bushler Bay. I was tired of small-town living, of my neighbours knowing my every move and of struggling with the conceptual quandaries of what to share of myself and how to interpret my observations and insights about the communities. A three-year interlude in Seattle followed during which I continued periodic fieldwork, analyzing data from the 
communities and working with friends to start a non-profit company (PACT, Professional Anthropologists Consulting Team). Michael and I sailed to Hawaii in 1978, where I began a second master's degree in international public health. The concluding part of that degree programme was a field study in a developing country. I chose Indonesia because of my earlier problems gaining permission to do research in the Middle East. The University of Hawaii School of Public Health had close ties with that country. In June 1979, I went to Bali to conduct my field study.

\section{Notes}

1 This chapter draws heavily on the following sources, as well as fieldnotes, personal journals and my own memories (Colfer and Colfer 1979, 1978; Colfer 1977, 1978, 1983).

2 Our work was to conduct ethnographic research in two communities, which I lump as Bushler Bay (Colfer and Colfer 1979). We were also to collaborate with Abt Associates' quantitative, cross-site research team from Cambridge, Massachusetts.

3 This vehicle involved a negotiation in which I argued for a car with good gas mileage and he, admitting that he'd always wanted a truck, argued for it as a rapport builder. He won.

4 The local population was almost exclusively white.

5 When the term Locals is capitalized, I refer to a social structural/cultural categorization.

6 In 1988, the Olympic National Forest harvested 264 million board feet of wood; by 1994 the harvest had declined to 8 million board feet (Headwaters Economics 2012).

7 Ballard and Huntsinger (2006) look at local knowledge of this product on the Peninsula.

8 We could also look at a lower scale and imagine separate harps for each subgroup, analogous to ethnic differences in Chapters 4 and 5.

9 This study may also contribute to Westberg and Powell's (2015) call for "scholarship that focuses on how femininity and masculinity are created, providing a critical analysis of the production and reproduction of gendered norms in bureaucratic settings" (p. 1235).

10 Most data about the school come from Colfer (1978).

11 Careful analysis of cases revealed that those women who genuinely needed the money fared worst of all within the school system. About half of all marriages at the time ended in divorce; there were plenty of women who needed to make a living.

12 Reed (2003) reports that "some women who were interviewed [in nearby Vancouver Island] chose not to risk challenging the "manliness' of their partner by taking a job" (p. 384). Women's sense of responsibility for the related emotional health of husbands is also reflected in Robinson and Hockey's (2011) study of masculinity in northern England.

13 Pascoe (2007), who studied a California school, notes, "The ordering of sexuality from elementary school through high school is inseparable from the institutional ordering of gendered identities" (pp. 26-27).

14 Temperatures range on average from $31^{\circ} \mathrm{F}$ to $45^{\circ} \mathrm{F}$ in January, with 54 inches of rain and many windy and cloudy days (www.worldclimate.com/climate/us/washington/ quilcene, accessed 7 November 2018).

15 See Anderson (2009) for an analysis of the traditional role of sports in supporting hegemonic masculinities and in differentiating valued heterosexual men from disvalued women and homosexual men in the US and UK.

16 Being a high school cheerleader was valued far more than being on girls' sports teams. Boys' sports were ubiquitous and much better supported than girls' sports (Colfer and Colfer 1979).

17 Blanchard's (1974) analysis of boys' and men's basketball games in New Mexico compares Navajo and Anglo Mormon approaches and values. The Anglos approached the game seriously and more similarly to the Bushler Bay community. The Navajo men, 
despite a cavalier attitude toward winning, called themselves the 'Warriors in Rimrock', while the Anglo team, whose interest depended on winning, called themselves, oddly, the 'Onions'.

18 This combination of cooperation and hierarchy fit more smoothly with one segment of the community (Public Employees) than the other (Locals) - a differentiation discussed below.

19 Pascoe (2007) describes the California cheerleaders as "working as football players' perky heterosexual helpmates" (p. 118).

20 Anderson (2009) notes that

Women, adult men, and other marginalized boys pay tribute to elite men by supporting them in the very arena in which they struggle to maximize their influence-athletic competitions. The epitome of this is when women cheer for male athletes, relegating themselves to symbolic subservience.

(pp. 44-45)

21 Also considered important in Jamaica (Tantam 2016): The football field "was a space for men to express themselves and compete over what it meant to be a successful man" (p. 222).

22 Locally competing masculinities are not unusual:

They [Bristol-Rhys and Osella] describe how the deployment of racial stereotypes by indigenous Emirati and migrant Asians centre on competing masculine ideals, infused with coloniality: for the Emirati, Indians are neutered, cast as effeminate non-men; for Indians, a reified notion of the male breadwinner becomes the measure against which the Emirati are found lacking.

(Cornwall 2016, p. 17)

23 Robinson and Hockey (2011) note in their study of masculinity in the UK:

In the statement 'I'm a suit man', man and suit are elided in a business world where men can be referred to simply as 'suits', one item of clothing standing for their entire occupational identity.

(p. 104)

See also Brandth and Haugen (2000) on the significance of attire in Norway's forests. Symbolic dress is also evident in upstate New York in 2020; professors at Cornell University wear slacks and a collared shirt; 'working men' visible at the diners around Ithaca's periphery are likely to wear jeans, T-shirts and work boots.

24 Colfer and Colfer (1979) quote a faculty member in 1974: "I tell you, Mike, you can't make a silk purse out of a sow's ear. These kids are culturally deprived. I feel more like a caretaker than a [teacher]" (p. 60).

25 Greig (2011) summarizes Paul Willis' 1981 ethnography of working-class teenage boys in the UK, which is reminiscent of Bushler Bay, but also uses class as a descriptor:

The study highlighted the young men's active and self-conscious cultivation of a 'traditional' working-class masculinity as a form of resistance to being labelled failures in the context of the middle-class aspirational values of school. Their gender practice became a source of class dignity that, in its rejection of education, only served to reproduce capitalist relations by ensuring workingclass kids stayed in working-class jobs.

26 McKay and Lucero-Prisno (2012) refer to a 2006 study in the US:

Working class labourers often celebrate a masculine 'pigness'-coarse, physically tough and aggressively heterosexual - to set themselves apart from more refined, effete professionals who lack 'real' manhood. 
27 Besides the school, Public Employees (mostly men) worked in the US Forest Service, Washington State Shellfish Lab, Washington State Fish Hatchery and the US Park Service. Women tended to conform to the values and behaviours aligned with their husbands' work, regardless of their own upbringing.

28 Reading the auto-ethnographic account of a Finnish woman's attempts to control her tears when confronted with devastating personal news (Katila 2019) can help us imagine the difficulty many men may have doing so. Kenyah men are allowed to cry (e.g., Chapter 6).

29 Cf. Silberschmidt's (2011) work in East Africa, showing how men who are unable to perform their socially defined roles as breadwinners turn to violence and extra-marital sexuality to maintain their self-respect as men. See also Alcaraz and Suárez (2006) on this pattern in Colombia or Barker and Ricardo (2006) in sub-Saharan Africa generally; also noted in the literature survey by Morris and Ratajczak (2019).

30 The same symbol, an apron, with a similar implication of loss of masculinity, is reported for aged men in urban Mexico (Varley and Blasco 2001).

31 Compare Hendriks' (2014) observations of Danish, French and Spanish loggers in a logging camp in the Democratic Republic of Congo:

The STIHL [a chainsaw manufacturer] pictures themselves play with stereotyped images of (white) masculinity and femininity and reconfirm the image of the logger as the paradigmatic masculine male and the chainsaw as the ultimate phallic object.

(p. 220)

32 DeMille and Lyons (2016) report, based on a study in Coastal British Columbia, that,

Historically manual tree falling has had a disproportionately high rate of fatal injuries. Syngatur (1998) reported that the rate of fatal injuries per 100,000 workers for manual tree fellers was 128.7 as compared to aircraft pilots (83.3), truck drivers (27.9), and farm occupations (27.5).

33 The emphasis on courage can be even stronger in areas where forest fires are common.

34 Like the Russian youth described by Walker (2016):

With apparently secure forms of low-skilled manual employment awaiting them after school, the lads [in a 1977 ethnography] were able confidently to reject the 'educational exchange' (of subservience for qualifications), and valorized manual over mental labor.

35 Apparently similar to McLeod (2016): "The stereotype of the 'Kiwi' male as pioneering, self-sufficient and strongly tied to the land is still a potent motif found in advertising and popular culture" in New Zealand (p. 227).

36 Connell links 'marginalized masculinities' with class or race. But within the Local context, bureaucrats, more highly valued in the broader society, are marginalized as unable or unwilling to 'perform' proper manhood.

37 'Peter' is a colloquial American term for the penis.

38 A pun on this common brand of log truck.

39 Robinson and Hockey (2011) note a similar masculine fascination with big trucks: firemen in the UK joined the service " "to ride the wagons' (fire engines)" [italics in original, p. 102]. The authors also describe hypersexuality similar to what Local women attribute to loggers.

40 Barker et al. (2011) report men's awareness of this attraction:

In one telling example, young men in a group session in Brazil said that if they became more sensitive, or gender-equitable, they wondered if they would convince young women in the community to go out with them. Young men 
argued, and young women in the group confirmed, that young women often like to go out with the 'bad guys'.

This 'naughty boy' syndrome is also found in Indonesia (see Chapters 4 and 5) and elsewhere.

41 Compare Miller (2009) on the Rarámuri of northern Mexico:

Rarámuri men gain respect when they take part in birth, and it is not shameful to talk about it because public expression of the fulfillment of a social obligation is part of the moral life of all Rarámuri. In this manner, men's active role in the reproductive process reaffirms ... the egalitarian and interdependent nature of the marriage bond as an essential feature of Rarámuri social organization.

(p. 341)

\section{References}

Alcaraz, Fredy Hernán Gómez, and Carlos Iván García Suárez. 2006. "Masculinity and Violence in Colombia: Deconstructing the Conventional Way of Becoming a Man." In The Other Half of Gender: Men's Issues in Development, edited by Ian Bannon and Maria C. Correia, 93-110. Washington, DC: The World Bank.

Altork, Kate. 1995. "Walking the Fire Line: The Erotic Dimension of the Fieldwork Experience." In Taboo: Sex, Identity, and Erotic Subjectivity in Anthropological Fieldwork, edited by Don Kulick and Margaret Willson, 107-139. London and New York: Routledge.

Anderson, Eric. 2009. Inclusive Masculinity. New York: Routledge.

Ballard, Heidi L., and Lynn Huntsinger. 2006. "Salal Harvester Local Ecological Knowledge, Harvest Practices and Understory Management on the Olympic Peninsula, Washington." Human Ecology 34:529-547. https://doi.org/10.1007/s10745-006-9048-7.

Barker, Gary, Marcos Nascimento, Christine Ricardo, Marianna Olinger, and Márcio Segundo. 2011. "Masculinnities, Social Exclusion and Prospects for Change: Reflections from Promundo's Work in Rio de Janeiro, Brazil." In Men and Development: Politicizing Masculinities, edited by Andrea Cornwall, Jerker Edström, and Alan Greig, 170-184. London: Zed Books.

Barker, Gary, and Christine Ricardo. 2006. "Young Men and the Construction of Masculinity in Sub-Saharan Africa: Implications for HIV/AIDS, Conflict and Violence." In The Other Half of Gender: Men's Issues in Development, edited by Ian Bannon and Maria C. Correira, 159-193. Washington, DC: The World Bank.

Blanchard, Kendall. 1974. "Basketball and the Culture Change Process: The Rimrock Navajo Case." Council on Anthropology and Education 5:8-13.

Brandth, Berit, and Marit S. Haugen. 2000. "From Lumberjack to Business Manager: Masculinity in the Norwegian Forestry Press.” Journal of Rural Studies 16:343-355.

Burwell, Lakota. n.d. "Environmental Factors Influencing Fire Behavior in the Olympic Mountains." Humboldt State University Capstone Project 476. www.nps.gov/olym/ learn/management/fire-history.htm.

Carroll, Matthew Stephen. 1985. Community and the Northwestern Logger: Continuities and Change in the Era of the Spotted Owl. Boulder, CO: Westview Press.

Colfer, Carol J. Pierce. 1975. "Bureaucrats, Budgets, and the BIA: Segmentary Opposition in a Residential School.” Human Organization 34 (2):149-156.

Colfer, Carol J. Pierce. 1977. Women's Communication and Family Planning in Rural America: The Case of Bushler Bay. Edited by D. Lawrence Kincaid. Vol. 4, Case Studies in Family Planning. Honolulu, HI: EWCI (Case Study \#4; reprinted 1978). 
Colfer, Carol J. Pierce. 1978. That All Men Are Created Equal . . Cambridge, MA: Abt Associates.

Colfer, Carol J. Pierce. 1983. “On Communication Among 'Unequals'.” International Journal of Intercultural Communication 7:263-283.

Colfer, Carol J. Pierce. 2018. "Before and After the 'Timber Wars': Context, Change and Potential Collaboration on the Olympic Peninsula." Humboldt Journal of Social Relations 40:137-162.

Colfer, Carol J. Pierce, Lee Cerveny, and Susan Stevens Hummel. 2019 "Using Rapid Rural Appraisal Tools to Explore Gender and Forests in the Global North." Human Organization 78 (1):12-27.

Colfer, Carol J. Pierce, with A. Michael Colfer. 1978. "Inside Bushler Bay: Lifeways in Counterpoint." Rural Sociology 42 (2):204-220.

Colfer, A. Michael, and Carol J. Pierce Colfer. 1979. Big Money, Small Change: Cultural Paradigms in an American Village. Cambridge, MA: Abt Associates.

Cornwall, Andrea. 2016. "Introduction: Masculinities under Neoliberalism." In Masculinities Under Neoliberalism, edited by Andrea Cornwall, Frank G. Karioris, and Nancy Lindisfarne, 1-28. London: Zed Books.

DeMille, Gregory John, and Kevin Lyons. 2016. "Unexpected Events When Manually Falling Trees in Coastal British Columbia." Forestry Science 62 (4):433-439. https:// doi.org/10.5849/forsci.15-164.

Greig, Alan. 2011. "Anxious States and Directions for Masculinities Work with Men." In Men and Development: Politicizing Masculinities, edited by Andrea Cornwall, Jerker Edström, and Alan Greig, 219-235. London: Zed Books.

Headwaters Economics. 2012. The Economy of the Olympic Peninsula and Potential Impacts of the Draft Congressional Watershed Conservation Proposal. Bozeman, MT: Wild Olympics Coalition.

Hendriks, Thomas. 2014. "Race and Desire in the Porno-tropics: Ethnographic Perspectives from the Post-colony." Sexualities 17 (1/2):213-229.

Katila, Saija. 2019. “The Mothers in Me.” Management Learning 50 (1):129-140. https:// doi.org/10.1177/1350507618780653.

McKay, Steven, and Don Eliseo Lucero-Prisno III. 2012. "Masculinities Afloat: Filipino Seafarers and the Situational Performance of Manhood." In Men and Masculinities in Southeast Asia, edited by Michele Ford and Lenore Lyons, 20-37. New York: Routledge.

McLeod, Carmen. 2016. "Ducks, Dogs, and Men: 'Natural' Masculinities in New Zealand Duck Hunting." In Masculinities Under Neoliberalism, edited by Andrea Cornwall, Frank G. Karioris, and Nancy Lindisfarne, 227-243. London: Zed Books.

Meyer, John C. 2000. "Humor as a Double-Edged Sword: Four Functions of Humor in Communication." Communication Theory 10 (3):1-33.

Miller, Janelli F. 2009. "Husband-Assisted Birth Among the Rarámuri of Northern Mexico." In Reconceiving the Second Sex: Men, Masculinity and Reproduction, edited by M. C. Inhorn, T. Tjornhoj-Thomsen, H. Goldbert, and M. L. C. Mosegaard, 327348. New York: Berghahn Books.

Morris, Edward W., and Kathleen Ratajczak. 2019. "Critical Masculinity Studies and Research on Violence Against Women: An Assessment of Past Scholarship and Future Directions." Violence Against Women 25 (16). https://doi.org/10.1177/1077801 219875827.

Newsweek. 1974. "The Riskiest Job of All.” Newsweek:64.

Pascoe, C. J. 2007. Dude, You're a Fag: Masculinity and Sexuality in High School. Berkeley, CA: University of California Press. 
Pingree, Melissa R. A., and Thomas H. DeLuca. 2018. “The Influence of Fire History on Soil Nutrients and Vegetation Cover in Mixed Severity Fire Regime Forests of the Eastern Olympic Peninsula, Washington, USA.” Forest Ecology and Management 422:95-107.

Reed, Maureen G. 2003. "Marginality and Gender at Work in Forestry Communities of British Columbia, Canada.” Journal of Rural Studies 19:373-389.

Robinson, Victoria, and Jenny Hockey. 2011. Masculinities in Transition. New York: Palgrave Macmillan.

Silberschmidt, Margrethe. 2011. "What Would Make Men Interested in Gender Equality? Reflections from East Africa." In Men and Development: Politicizing Masculinities, edited by Andrea Cornwall, Jerker Edström, and Alan Greig, 98-110. London: Zed Books.

Syngatur, E. F. 1998. "Logging Is Perilous Work." Compensation and Working Conditions (winter):9. www.bls.gov/opub/mlr/cwc/logging-is-perilous-work.pdf, accessed 12 February 2016.

Tantam, William. 2016. "Football Field, Bar and Street Corner: Sports, Space and Masculinities in Rural Jamaica." In Masculinities Under Neoliberalism, edited by Andrea Cornwall, Frank G. Karioris, and Nancy Lindisfarne, 213-226. London: Zed Books.

Varley, Ann, and Maribel Blasco. 2001. "Exiled to the Home: Masculinity and Ageing in Urban Mexico." In Men at Work: Labour, Masculinities, Development, edited by Cecile Jackson, 115-138. Portland, OR: Frank Cass with EADI (European Association of Development Research and Training Institutes, Bonn).

Walker, Charlie. 2016. "In Search of 'Stability:' Working-class Men, Masculinity and Wellbeing in Contemporary Russia." In Masculinities Under Neoliberalism, edited by Andrea Cornwall, Frank G. Karioris, and Nancy Lindisfarne, 51-65. London: Zed Books Ltd.

Westberg, Lotten, and Stina Powell. 2015. "Participate for Women's Sake? A Gender Analysis of a Swedish Collaborative Environmental Management Project." Society \& Natural Resources 28 (11):1233-1248. https://doi.org/10.1080/08941920.2015.1014594. 